\title{
Emergy analysis for tourism systems: Principles and a case study for Macao
}

\author{
Kampeng Lei ${ }^{\mathrm{a}, \mathrm{b}, \mathrm{d}}$, Shaoqi Zhou ${ }^{\mathrm{a}, \mathrm{b}}$, Dan $\mathrm{Hu}^{\mathrm{c}, *}$, Zhen Guo ${ }^{\mathrm{c}}$, Aixin $\mathrm{Cao}^{\mathrm{c}}$ \\ ${ }^{a}$ College of Environmental Science and Engineering, South China University of Technology, Guangzhou 510641, China \\ b State Key Laboratory of Subtropical Building Sciences, South China University of Technology, China \\ 'State Key Lab of Urban E Regional Ecology, Research Center for Eco-Environmental Sciences, Chinese Academy of Sciences, Beijing 100085, China \\ ${ }^{\mathrm{d}}$ Macao Science and Technology Association, Macao, China
}

\section{A R T I C L E I N F O}

\section{Article history:}

Received 4 March 2010

Received in revised form 26 January 2011

Accepted 17 February 2011

Available online 6 April 2011

\section{Keywords:}

Ecological energy accounting

Emergy

Tourism

Macao

\begin{abstract}
A B S T R A C T
To support a sustainable combined ecological and economic system, the flows and quantities of emergy must be in balance; that is, a net surplus of emergy must flow into the system to account for the fact that socioeconomic systems are rarely self-sustaining. When this flow is not available, the system will degrade. Although emergy synthesis is a better method for measuring the sustainability of an economic system than simplistic quantification of monetary flows, it is difficult to evaluate specific systems such as tourism due to a lack of sufficient data and the lack of a powerful accounting method for materials and energy flows. Thus, published articles often unclearly or incorrectly use emergy accounting for ecotourism. To permit this use, it is important to understand the advantages and drawbacks of the various emergy accounting approaches so that the correct technique can be used to assess the sustainability of tourism at local or national levels. In this paper, we examined the following emergy issues: comparing the four main emergy accounting approaches available for studying tourism flows, distinguishing the consumption of emergy by tourists from the equivalent emergy their expenditures could purchase, and showing how these approaches work using a case study of tourism in Macao from 1983 to 2007.
\end{abstract}

(c) 2011 Elsevier B.V. All rights reserved.

\section{Introduction}

As one of the world's largest and fastest growing industries, tourism is placing great stress on biologically diverse habitats and indigenous cultures, which are often used to support large-scale tourism activities. The governments and tour operators who are engaged in promoting sustainable tourism are sensitive to these dangers and seek to protect tourist destinations from unsustainable use so they can protect their tourism industry. To permit sustainable tourism, environmental integrity and economic development should be assessed using a suitable measurement system. Since human systems (and especially cities) concentrate materials and energy obtained from outside the system boundaries (i.e., human socioeconomic systems are rarely self-sustaining), one of the earliest modern ecological approaches to urban systems was the assessment of biogeochemical budgets of whole cities (Odum and Odum, 1980). For a tourism city, the large exchanges of materials and energy with the external environment are accompanied by large flows of money to sustain tourists, tourism equipment and infrastructures, and tourist services.

\footnotetext{
* Corresponding author. Tel.: +86 106284 9199; fax: +86 1062943807 .

E-mail address: hudan@rcees.ac.cn (D. Hu).
}

Odum (1996) set up a system for quantifying flows of ecological energy ("emergy accounting", in which emergy represents "embodied energy") that was capable of objectively evaluating combined ecological and economic systems. Regardless of whether a key driver of the system is measured in energy, mass, or money units, emergy synthesis can convert all of these flows into their ultimate equivalents based on the amount of solar energy required to generate these flows. Ulgiati and Brown (2009) explored "the way energy and material resources of different quality flow through ecosystems" and discussed the "ecosystem complexity" resulting from changes in emergy, empower, and transformity. Emergy, a unit of resource use and work potential, has been used to quantitatively evaluate the sustainability and condition of a system across both temporal and spatial scales in many different fields since 1990 (Huang and Odum, 1991; Huang, 1998; Johansson et al., 2000; Brandt-Williams, 2001; Brown and Buranakarn, 2003; Campbell, 2004; Cuadra and Rydberg, 2006; Zhang et al., 2008; Li and Wang, 2009; Lei et al., 2010; Ren et al., 2010).

The World Tourist Organization (WTO) defines sustainable tourism development as a "form of development, provision of amenities, or tourist activity that emphasizes respect for and longterm preservation of natural, cultural, and social resources and makes a positive and equitable contribution to the economic development and fulfillment of people living, working, or staying 
in these areas" (Franklin, 2003). Since 2000, emergy synthesis has been introduced to measure the sustainability of tourism systems (Abel, 2000, 2003; Brown and Ulgiati, 2001a; Lei and Wang, 2008; Vassallo et al., 2009; Lei et al., 2010). Abel (2000, 2003) addressed the problem of emergy synthesis for ecotourism on Bonaire Island in the Caribbean. Brown and Ulgiati (2001a) studied resorts in Mexico and Papua New Guinea. Lei and Wang (2008) studied the tourism industry of Macao, and found that tourist consumption could be quantified using emergy accounting, and calculated as a proportion of the total emergy use by the host country (Lei et al., 2006). Vassallo et al. (2009) used the tourism area life cycle model to investigate the emergy flow of tourists and residents for an Italian coastal resort region, and found that emergy synthesis could be used to assess a tourist region's sustainability. Lei et al. (2010) studied the use of emergy accounting to assess the main branch of tourism in Macao, namely the gambling sector, by following the food, tickets, services, water, electricity, equipment, labor, and other services that consume large quantities of materials and energy. In this article, we discuss the different approaches that have been taken to permit emergy accounting, and discuss their relative suitability, key characteristics, and the sustainability of tourism judged based on these approaches.

\section{Methodology}

\subsection{Approaches used in tourism emergy accounting}

Tourism is an industry with high consumption of energy and other natural resources. As a result, many tourist destinations operate at lower ecological efficiency than the global average (Gössling et al., 2005). Sustainable tourism has thus become an increasingly important concern, and there is broad consensus that the industry's environmental impacts can no longer be ignored (Hunter and Green, 1995). Ecotourism projects seem more environmentally benign, but since they are often assessed purely at a local level (i.e., ignoring external inputs into the system), even ecotourism may not be sustainable from a broader perspective. An advantage of the concept of emergy proposed by Odum (1996) is that this approach explicitly attempts to measure flows into and out of the ecological and economic components of a system. Emergy quantifies energy, materials, and environmental and human services within a common framework while accounting for differences in the quality of the energy and resources that are consumed. Another advantage of emergy analysis is that it explicitly places a value on the services provided by the environment, which were traditionally considered to be free and outside the monetary economy that is emphasized in conventional economics (Brown and Ulgiati, 2001b).

However, there have been four main approaches used in emergy analysis for tourism, with different scopes of applicability and different analytical tradeoffs (Table 1). In our previous research (Lei et al., 2006, 2008; Lei and Wang, 2008), we studied tourism emergy for Macao using the emergy accounting approach. Here, we will discuss the relevance of the four approaches, with data from our previous studies supplemented by new data from 2007 in the emergy calculations; the resulting analysis does a better job of accounting for the unique characteristics of tourism.

\subsubsection{Approach 1: conversion of money flows into emergy}

In recent research, most authors have treated the monetary flows from tourism as an income source (Ulgiati et al., 1994; Huang and Odum, 1996; Brown and Ulgiati, 2001a; Lan et al., 2002; Jiang et al., 2008; Zhang et al., 2009), and have treated these incomes as a kind of external input (i.e., an investment) for a regional ecosystem (Fig. 1, Approach 1). The solar emergy of the tourism system is simply calculated by multiplying the quantity of money by a conversion factor $(\mathrm{Em} / \$)$ specific to the system being studied. The imported emergy of tourism $\left(T_{\mathrm{m}}\right)$ is calculated as follows:

$T_{\mathrm{m}}=\left(\frac{E m}{\$}\right) C_{\mathrm{t}}$

where $E m / \$$ is an emergy conversion factor for monetary flows and $C_{\mathrm{t}}$ is the income from tourism. Since the concept of tourism emergy has been expressed differently by different researchers, it is important to define emergy in terms of emergy-exchange processes (Fig. 2), as described in the following paragraphs.

Embodied emergy of the tourist (i.e., the emergy imported from the tourist's home country): Brown and Ulgiati (2001a) proposed that the $\mathrm{Em} / \mathrm{\$}$ ratio from a tourist's home country should be included in the analysis. When tourists visit a host country, the embodied emergy that they bring with them corresponds to their country's technology and the condition of its resources. Although we agree with Brown's opinion, we employed the global $\mathrm{Em} / \$$ ratio in our research because tourists typically come from many different countries with very different $\mathrm{Em} / \mathrm{\$}$ ratios, and there is insufficient data available to let us calculate a weighted-average emergy value for the tourists who came to Macao in each year of our study period; this is a particular problem for Macao, which is the subject of our case study later in this paper, because most tourists come from China, and emergy data for China is generally lacking.

Table 1

Summary of the approaches used for tourism emergy analysis.

\begin{tabular}{|c|c|c|c|c|}
\hline Approach & Applicability & Emergy accounting & Problems & Advantage \\
\hline 1 & $\begin{array}{l}\text { A country or region. Detailed statistical } \\
\text { data is available }\end{array}$ & $\begin{array}{l}\text { Simply convert the money } \\
\text { flows into emergy flows by } \\
\text { multiplying the money by a } \\
\text { conversion factor (Em/US\$) }\end{array}$ & $\begin{array}{l}\text { There is debate over which } \mathrm{Em} / \\
\text { US\$ conversion factor should be } \\
\text { employed }\end{array}$ & Easy to calculate \\
\hline 2 & $\begin{array}{l}\text { A single resort. Detailed data is } \\
\text { available }\end{array}$ & Emergy accounting & $\begin{array}{l}\text { A single resort provides limited } \\
\text { insight into the problems of } \\
\text { larger-scale systems }\end{array}$ & Easy to calculate \\
\hline 3 & $\begin{array}{l}\text { Two or more resorts in a small } \\
\text { area. Detailed data is available }\end{array}$ & Emergy accounting & $\begin{array}{l}\text { A small number of resorts may } \\
\text { still provide limited insights } \\
\text { into larger-scale systems }\end{array}$ & Easy to calculate \\
\hline 4 & $\begin{array}{l}\text { Many resorts distributed throughout } \\
\text { a region. Aggregate data is available } \\
\text { for the region }\end{array}$ & $\begin{array}{l}\text { The proportion of total emergy } \\
\text { use accounted for by tourist } \\
\text { consumption is multiplied by } \\
\text { the total emergy that is } \\
\text { consumed by the system }\end{array}$ & $\begin{array}{l}\text { The weight used for the tourist } \\
\text { consumption factor }{ }^{\mathrm{a}} \text { must be } \\
\text { determined from statistics and } \\
\text { surveys of the relative emergy } \\
\text { consumption by the average } \\
\text { tourist and the average local } \\
\text { resident }\end{array}$ & $\begin{array}{l}\text { Suitable for analysis at larger } \\
\text { scales (e.g., systems or } \\
\text { countries) }\end{array}$ \\
\hline
\end{tabular}

\footnotetext{
${ }^{\text {a }} r$ varies among countries and regions as a result of different consumption styles. In Macao, $r$ is about 1.9 (Lei and Wang, 2008 ).
} 

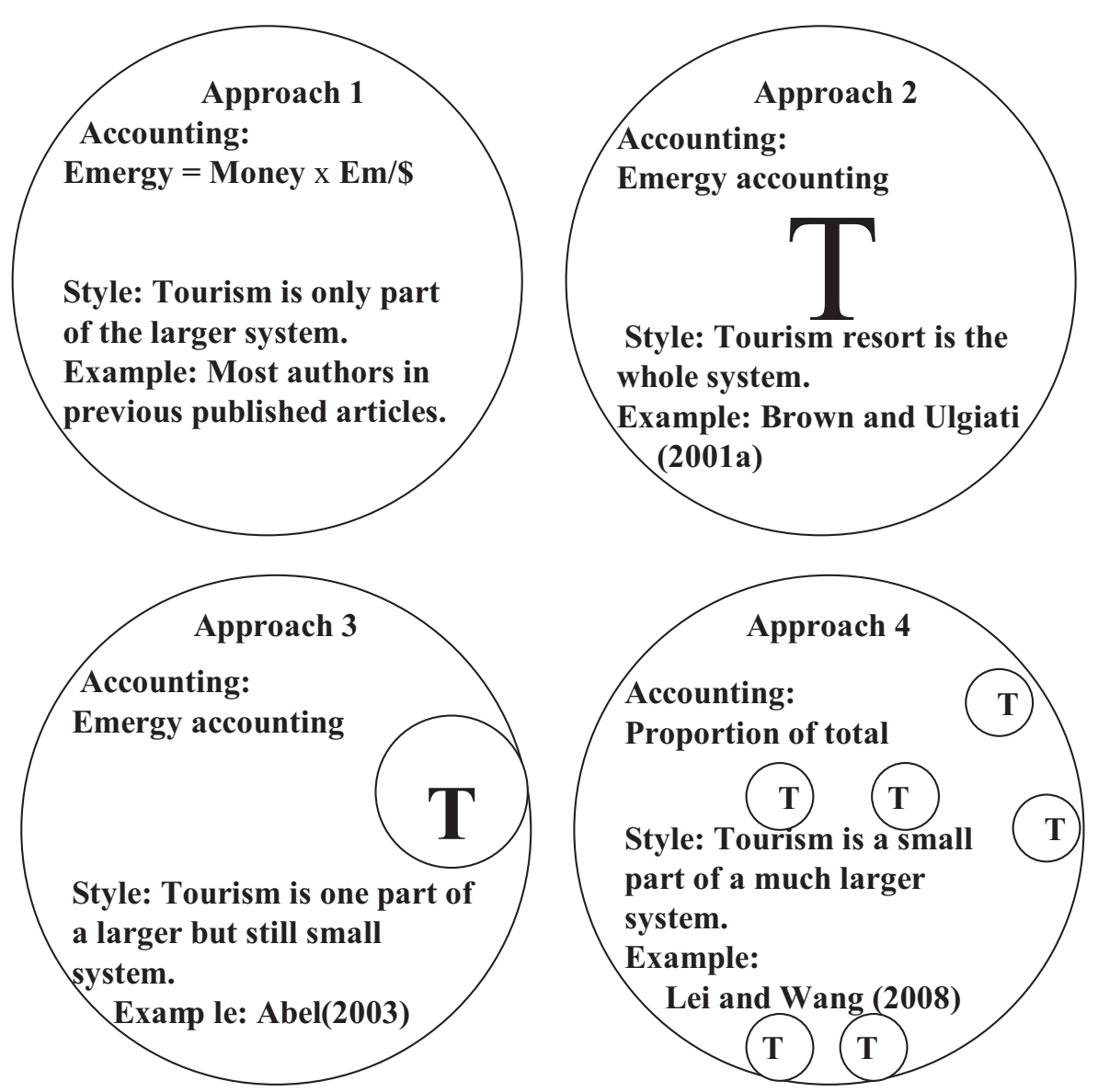

Fig. 1. The four main approaches used in tourism emergy accounting. Here, "T" represents tourist resorts.

The emergy consumed by tourists (i.e., the emergy supplied by the host country): The previous paragraph accounts for emergy imports that accompany tourists, but we must also account for the emergy of the goods and services they consume in their host country. By accounting for the quality of each good and service and for the real (emergy) value of the environmental services that sustain tourism, resources are not valued solely by their cost or by society's willingness to pay, and the environmental externalities that are often ignored by purely economic analyses are implicitly included in the analysis, thereby making it impossible to account for the environmental consequences of the economic activities (Baumgärtner and Quaas, 2010).

The conversion of monetary expenditures by tourists into emergy and the problem of "double counting": This aspect of emergy should be distinguished in emergy accounting to avoid "double counting", since the money is used to purchase energy, goods, and services from outside the system being studied, and these purchases maybe have already been accounted for when flows of these inputs into a tourism system are calculated (Lei et al., 2008).

Some authors treat tourism as an emergy export (Huang and Odum, 1996; Odum, 1996; Abel, 2000), since the goods and services leave the host region and are exported to the tourist's home region; on this basis, tourism emergy can be depicted as another "export" industry. Goods and services provided by a host region are purchased by foreigners who use hotel facilities, eat in restaurants, and buy goods (Abel, 2000), and these aspects of consumption can therefore be thought of as the exported emergy (Fig. 2) of tourism (Lei et al., 2008). However, it is important to note that this description may be too simplistic. Some emergy is clearly not exported (e.g., money lost during gambling remains within the host region) and some is clearly exported (e.g., goods that are purchased as souvenirs and that are returned to tourist's the home country). In future research, it would be helpful to develop methods to distinguish between the two categories of emergy.

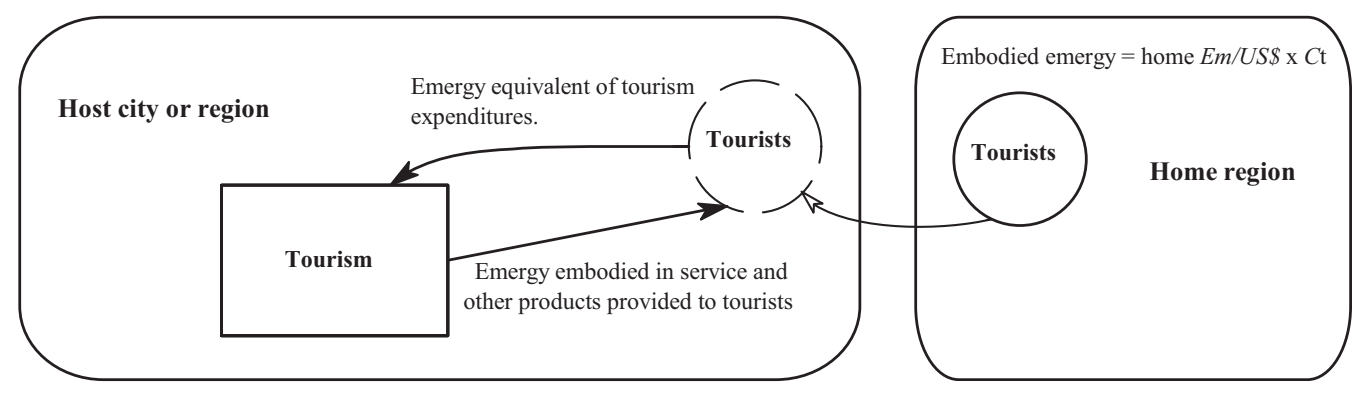

Fig. 2. An emergy-exchange diagram for a tourist resort and its host city or region (modified from Lei et al., 2008). 


\subsubsection{Approach 2: emergy synthesis for a single resort}

Brown and Ulgiati (2001a) studied tourism resorts in Papua New Guinea and Mexico. The first was a small diving resort on the Island of New Britain; the second was a large hotel resort complex in the city of Puerto Vallarta. They proposed that sustainable tourism development was related to the net emergy benefits for the host region, and that sustainability resulted from a positive emergy balance. Their paper outlined a method for determining the carrying capacity for economic investments based on an emergy evaluation using tourism development data for the two host regions (Fig. 1, Approach 2).

The total annual resource use by the tourist resorts and the economies in which they were embedded was calculated and converted into emergy units, mostly using materials and energy terms and with limited use of money emergy. The used the following equation:

Emergy $=\tau E$

where $E$ is the available energy or mass and $\tau$ is the transformity.

\subsubsection{Approach 3: emergy synthesis for a small area}

Abel performed an emergy synthesis analysis for ecotourism as part of an interdisciplinary study conducted on the island of Bonaire in the Netherlands Antilles (Abel, 2000, 2003). Abel modeled ecotourism development on Bonaire in terms of emergy perturbations of a complex combined human-ecological system (Abel, 2003). New emergy flows associated with ecotourism fueled transformations of the island's ecology and of its sociocultural system. Tourism emergy inflows included the following: transportation, which is an essential ingredient because tourists could not reach the island without it; local services, in both direct and indirect forms, which were required to maintain and promote the hotel industry; imported goods, including the emergy of shipping and foods, which were present in the emergy inflows from the retail subsystem; and labor, since tourists require a large amount of support from tourism staff, and the emergy inflow from this labor is substantial. Abel considered the sum of these emergy inputs to represent the emergy exports of tourism, which flow to the tourists, although exchange processes may occur within the host region (Fig. 1, Approach 3; Fig. 3). Vassallo et al. (2009) performed a similar case study for an Italian coastal resort region and obtained results similar to those of Abel (2000).

\subsubsection{Approach 4: tourism emergy as a proportion of total emergy use}

In some cases, detailed statistics on energy, materials, and money flows are available for a region, and this abundance of data allows researchers to calculate the overall emergy use in that region. If insufficient amounts of detailed data are available for the tourism sector, its emergy flows can sometimes be approximated satisfactorily if the proportion of the overall emergy flows accounted for by tourism can be estimated. For example, Macao is a tourism-dominated city with a large number of tourists (Fig. 1,
Approach 4). Since the resources of such tourism cities are shared by both local residents and tourists, consumption by the tourists can be accounted for as a proportion of the total emergy used by the host region (Lei et al., 2006, 2008). Therefore, the emergy consumed by tourists $\left(M_{\mathrm{t}}\right)$ can be estimated as follows:

$M_{\mathrm{t}}=R_{\mathrm{t}} U$

where $R_{\mathrm{t}}$ is the proportion of total emergy use $(U)$ that is consumed by tourists. $R_{\mathrm{t}}$ can be calculated as follows:

$R_{\mathrm{t}}=\frac{T d r}{T d r+365 P}$

where $T$ represents the total number of tourists, $d$ is the average number of days that a tourist stays in the host region, $P$ represents the population of Macao, and $r$ is the consumption factor for the tourists. In our previous research (Lei et al., 2008), we investigated an $r$ value of 1.9 , which means that a tourist consumes 1.9 times the emergy consumed by a local resident. In our updated 2007 study of Macao, the resulting $R_{\mathrm{t}}$ was 0.267 .

This approach recognizes the fact that tourism destinations are shared by local residents and tourists, and that tourist consumption represents a calculable proportion of the total emergy used by the host region (Lei et al., 2006; Lei and Wang, 2008).

\subsection{Two emergy flows for tourism: what you paid for and what you got}

It can be shown (Fig. 2) that the emergy of the money that tourists spend in the host region does not equal the emergy they consume (Lei et al., 2008). To express the difference between spending and consumption in the emergy-exchange processes between the tourism sector and the tourists, we have proposed a more reasonable method for calculating the emergy consumed by tourists $\left(M_{\mathrm{t}}\right)$. This method is based on holistic analysis, and combines the above two calculation methods. The buying-power emergy represents what the tourists spend $\left(T_{\mathrm{m}}\right)$, and what the tourists consume $\left(M_{\mathrm{t}}\right)$ represents a different quantity (Fig. 3); the two flows travel in opposite directions and can have very different values (Lei et al., 2008), but our method accounts for both flows.

\section{Emergy analysis and discussion: a case study of tourism in Macao}

\subsection{Introduction to tourism in Macao}

Because of its unique mixture of Portuguese and Chinese cultures, Macao makes an interesting destination for tourists from around the world. Although Macao's rising reputation as a gambling heaven, spurred by the development of ever larger and grander casinos, is a major attraction for many, there are also beaches, historical sites (fortresses, churches, temples, and gardens), and excellent museums to explore. Since 2005, Macao

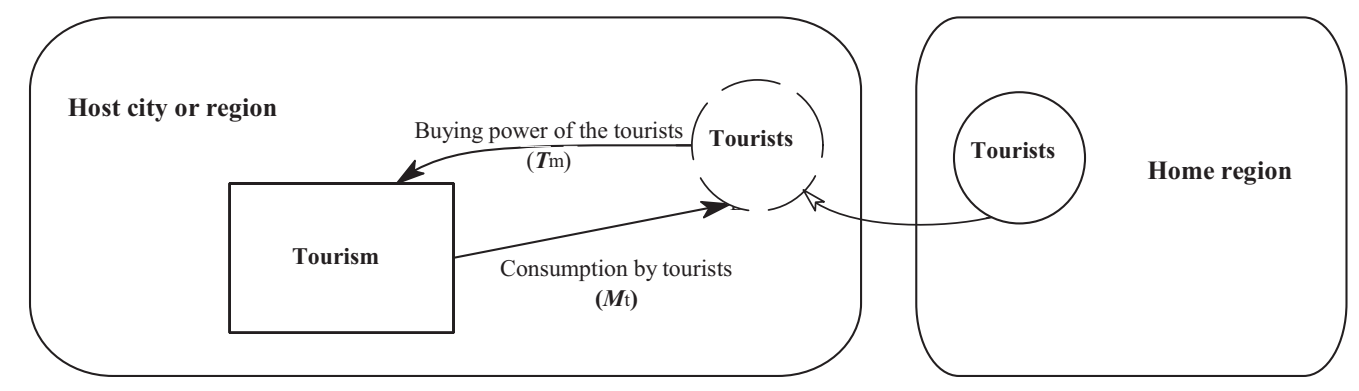

Fig. 3. An emergy-exchange diagram for a small tourist resort region composed of multiple resorts (modified from Lei et al., 2008). 
Table 2

Annual emergy flows for renewable $(R)$ and nonrenewable $(N)$ resources for Macao in 2007.

\begin{tabular}{|c|c|c|c|c|c|c|}
\hline Categories & Item & Raw units & $\begin{array}{l}\text { Transformity } \\
\text { (sej/unit) }\end{array}$ & Emergy (sej) & $\begin{array}{l}\text { Emdollars } \\
(\mathrm{em} \$)\end{array}$ & Source of transformity \\
\hline \multirow[t]{7}{*}{ Renewable } & 1. Sunlight & $1.50 \times 10^{17} \mathrm{~J}$ & 1 & $1.50 \times 10^{17}$ & $8.22 \times 10^{4}$ & Odum (1996) \\
\hline & 2. Wind, kinetic & $6.86 \times 10^{13} \mathrm{~J}$ & 663 & $4.55 \times 10^{16}$ & $2.50 \times 10^{4}$ & Campbell et al. (2005) \\
\hline & 3. Rain, chemical & $2.12 \times 10^{14} \mathrm{~J}$ & 18,199 & $3.85 \times 10^{18}$ & $2.11 \times 10^{6}$ & Campbell et al. (2005) \\
\hline & 4. Rain, geopotential & $4.20 \times 10^{13} \mathrm{~J}$ & 10,488 & $4.40 \times 10^{17}$ & $2.41 \times 10^{5}$ & Campbell et al. (2005) \\
\hline & 5. Tide & $1.17 \times 10^{13} \mathrm{~J}$ & 16,842 & $1.97 \times 10^{17}$ & $1.08 \times 10^{5}$ & Campbell et al. (2005) \\
\hline & 6. Waves & $1.17 \times 10^{15} \mathrm{~J}$ & 30,550 & $3.59 \times 10^{19}$ & $1.97 \times 10^{7}$ & Odum (1996) \\
\hline & 7. Earth cycles & $4.23 \times 10^{13} \mathrm{~J}$ & 34,377 & $1.46 \times 10^{18}$ & $7.99 \times 10^{5}$ & Campbell et al. (2005) \\
\hline Total $(5+6+7)$ & & $1.23 \times 10^{15} \mathrm{~J}$ & & $3.75 \times 10^{19}$ & & \\
\hline \multirow[t]{2}{*}{ Nonrenewable } & 1. Stone & $3.60 \times 10^{11} \mathrm{~g}$ & $1 \times 10^{9}$ & $3.60 \times 10^{20}$ & $1.98 \times 10^{8}$ & Odum (1996) \\
\hline & 2. Topsoil loss & $1.90 \times 10^{9} \mathrm{~g}$ & 62,500 & $1.19 \times 10^{14}$ & $6.52 \times 10$ & Odum (1996) \\
\hline Total $(1+2)$ & & $3.62 \times 10^{11} \mathrm{~g}$ & & $3.98 \times 10^{20}$ & $1.98 \times 10^{8}$ & \\
\hline
\end{tabular}

Data source: Statistics and Census Service (2008).

has been officially listed as a World Cultural Heritage Site (Lei et al., 2008).

Tourism is a vital part of Macao's economy, accounting for $1.449 \times 10^{9}$ US\$, which amounted to about $75.7 \%$ of its GDP (Statistics and Census Service, 2008) in 2007. The tourism sector has become Macao's main source of revenue, as the city's other industries have declined due to competition from neighboring regions since 1992 . Tourism employed more than $40 \%$ of the working population in 2007 (Statistics and Census Service, 2008).

\subsection{Emergy accounting for Macao's tourism sector}

To focus on the core features of tourism emergy, we obtained extensive data on the flows of energy, money, and materials into and out of Macao's socioeconomic and environmental systems. This data is provided as Supplemental Tables S1-S7. Here, we have only presented the most relevant data in the form of summary tables. Table 2 summarizes the renewable $(R)$ and indigenous nonrenewable $(N)$ resources. In our research, we used the most recent emergy baseline for Earth's geobiosphere, namely $15.8 \times 10^{24} \mathrm{sej} / \mathrm{J}$, but we did not modify the transformities of the items included in our analysis because the new baseline produced only minor changes in the transformities (Brown and Ulgiati, 2010). Table 3 summarizes the emergy exchanges (imports versus exports) and Table 4 summarizes the main emergy flows for Macao in 2007.

In Macao, tourism is the economy's main engine, and it can be thought of as an emergy-earning industry. In 2007, nearly 27 million tourists visited Macao; this is about 51.3 times its population (Table 5). The majority of tourists came from Mainland China (55.1\%), Hong Kong (30.3\%), and Taiwan (5.3\%). The average spending by tourists was US $\$ 203.70$, and the average duration of their stay was 1.36 days. In 2007, tourism brought in a gross income of US\$14.5 billion. Revenue from gambling was US\$10.2 billion, which was $70.4 \%$ of the total annual tourism revenues (Statistics and Census Service, 2008). Tourism contributed an estimated $75.7 \%$ of the GDP in 2007.

Table 3

Emergy evaluation for Macao's imports and exports in 2007.

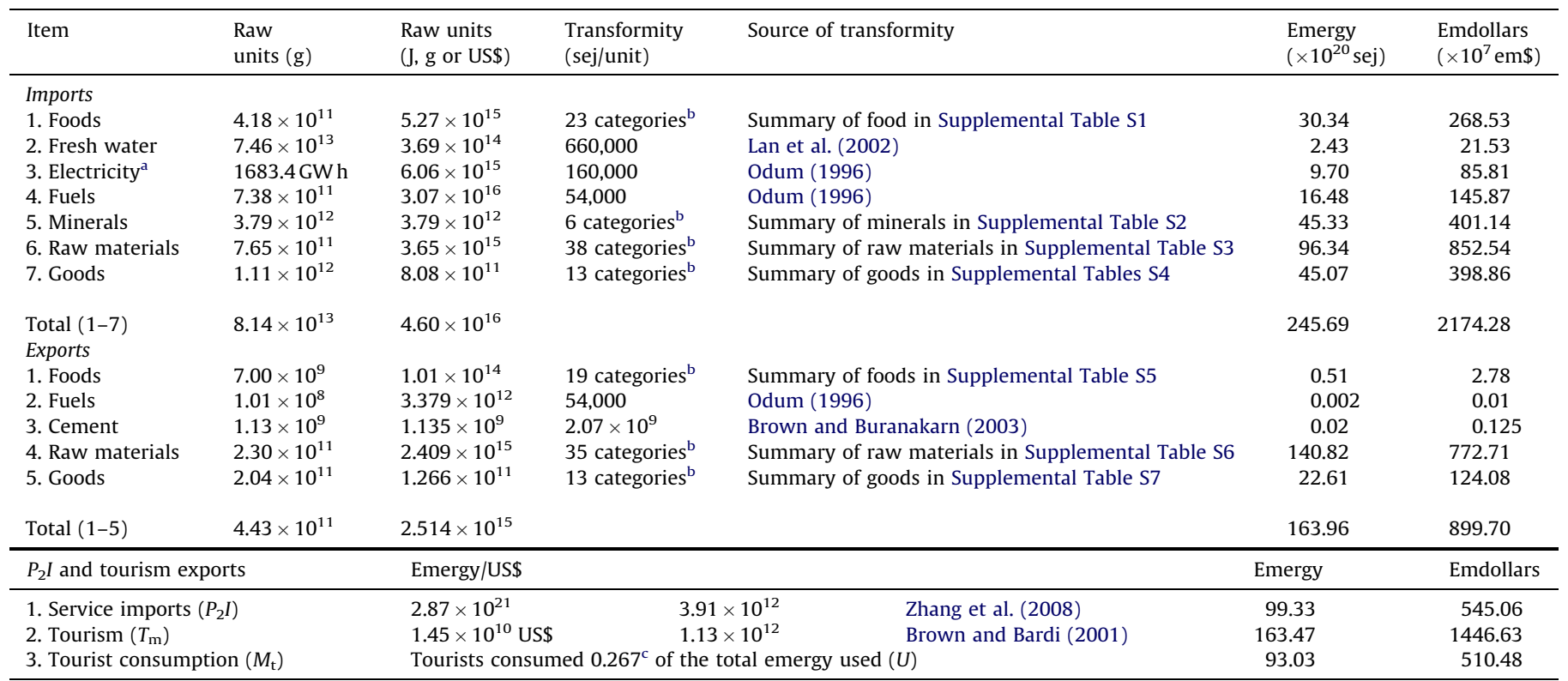

Data source: Statistics and Census Service (2008).

a The electricity purchased from China totalled $1683 \mathrm{GWh}$, for an equivalent energy of $6.06 \times 10^{15} \mathrm{~J}$.

b We have presented the raw data used to calculate certain values in this table as Supplemental Tables.

c $R_{t}$ was calculated using Eq. (4) 
Table 4

Summary of the main emergy flows for Macao in 2007.

\begin{tabular}{|c|c|c|c|c|}
\hline Variable & Item & Energy $(\mathrm{J})$ or mass $(\mathrm{g})$ & Solar emergy $\left(\times 10^{20}\right.$ sej $)$ & Emdollars $\left(\times 10^{9} \mathrm{em} \$\right)$ \\
\hline$R$ & Renewable resources (Table 2) & $1.23 \times 10^{15}$ & 0.38 & 0.02 \\
\hline$N$ & Nonrenewable resources (Table 2) & $3.62 \times 10^{11}$ & 3.6 & 0.20 \\
\hline Fuel & Imported fuels and minerals (Table 3 ) & $3.67 \times 10^{16}$ & 71.51 & 3.92 \\
\hline$G$ & Imported foods, goods, and raw materials (Table 3 ) & $9.29 \times 10^{15}$ & 174.19 & 9.56 \\
\hline$P_{2} I$ & Imported services (Table 3 ) & $2.54 \times 10^{9}$ & 99.33 & 5.45 \\
\hline IMP & Imported emergy (fuel $+G+P_{2} I$ ) & $4.60 \times 10^{16}$ & 345.03 & 18.93 \\
\hline$U$ & Emergy used $(R+N+I M P)$ & $4.73 \times 10^{16}$ & 349.00 & 19.15 \\
\hline$B$ & Exported production (Table 3 ) & $2.51 \times 10^{15}$ & 163.96 & 9.00 \\
\hline EXP & Exported emergy $\left(B+M_{\mathrm{t}}\right)$ & $1.51 \times 10^{16}$ & 256.99 & 14.10 \\
\hline ELE & Electricity (3136.9 GW h) & $1.13 \times 10^{16}$ & 18.07 & 0.99 \\
\hline
\end{tabular}

The data from Statistics and Census Service (2008) show that the mean duration of a tourist's stay in Macao has slowly decreased, but spending on non-gambling activities has also gradually increased. In 1983, there were only 4.1 million tourists, but that total reached nearly 27 million in 2007 (an increase to nearly 6.6 times the 1983 value). The number of tourists amounted to 14.5 times Macao's population in 1983, but this ratio increased to 51.3 in 2007 (Table 5). The tourism indicators increased steadily from 1983 to 2007 (Fig. 4), except between 1997 and 1999. Since 2000, the economy of Macao has grown more rapidly than during previous periods, primarily as a result of growth in the gambling and tourism industries.

During the 1980s, the manufacturing industry contributed important benefits to Macao's economy, particularly after China opened its doors to the world market. However, this sector has lost this advantageous situation since 1990 due to competition from Chinese and southeast Asian rivals. As a result, gambling and tourism became increasingly important to Macao's economy and accounted for an increasingly large proportion of the government's revenues. Fig. 4 shows the trends in GDP, tourism income, gambling income, government revenues, and gambling tax revenues from 1983 to 2007; all five curves show parallel changes, with only slight differences in the slopes of the curves. The proportion of government revenues accounted for by gambling taxes increased from between 38\% in 1983 and 50.1\% in 1995 to $76.1 \%$ in 2007 . The GDP increased slowly at first, from US $\$ 1.1 \times 10^{9}$ in 1983 to US\$7.0 $\times 10^{9}$ in 1997 . After a brief decrease to US $\$ 6.2 \times 10^{9}$ in 2001 , it increased rapidly to US\$19.2 $\times 10^{9}$ in 2007 (Table 5).

The proportions of GDP accounted for by Macao's tourism and gambling industries have increased in parallel with increases in their proportions of total emergy use (Fig. 5). In monetary terms, only man-made capital is accounted for, so the proportions of tourism and gambling income were higher in monetary terms (as a proportion of GDP) than in emergy terms (as a proportion of $U$ ). The emergy synthesis analysis for tourism fully accounts for both environmental resources and economic services, and therefore provides a more fair and reasonable accounting than simply accounting for monetary values. However, both proportions of the total increased steadily from 1983 to 2004, except for a brief period between 1997 and 1999. The percentage of GDP accounted for by tourism increased from $44.0 \%$ in 1983 to $75.7 \%$ in 2007; during the same period, the proportion of GDP accounted for by gambling revenues rose from $18.3 \%$ to $53.3 \%$. On an emergy basis, the proportion of total emergy use $(U)$ accounted for by tourism rose from $11.1 \%$ in 1983 to $46.8 \%$ in 2007 , versus a corresponding increase for the gambling component from $4.6 \%$ to $33.0 \%$.

Table 5

Emergy and tourism-related indicators for Macao from 1983 to 2007.

\begin{tabular}{|c|c|c|c|c|c|c|c|c|c|c|c|c|}
\hline Indicators & 1983 & 1985 & 1988 & 1990 & 1993 & 1995 & 1997 & 1999 & 2000 & 2003 & 2004 & 2007 \\
\hline Population & 282,843 & 289,704 & 315,997 & 334,961 & 383,984 & 409,300 & 422,000 & 429,600 & 437,500 & 448,495 & 465,333 & 525,800 \\
\hline GDP $\left(\times 10^{9}\right.$ US $\left.\$\right)$ & 1.15 & 1.37 & 2.33 & 3.26 & 5.67 & 6.94 & 7.01 & 6.1 & 6.19 & 7.9 & 10.31 & 19.15 \\
\hline Tourists $\left(\times 10^{6}\right)$ & 4.1 & 4.18 & 5.54 & 5.94 & 6 & 5.99 & 7 & 7.44 & 9.16 & 11.89 & 16.67 & 26.99 \\
\hline $\begin{array}{l}\text { Mean duration of } \\
\text { visit (days) }\end{array}$ & 1.9 & 1.8 & 1.7 & 1.7 & 1.6 & 1.5 & 1.4 & 1.4 & 1.3 & 1.2 & 1.13 & 1.36 \\
\hline Tourism income $\left(\times 10^{9} \text { US\$ }\right)^{\mathrm{a}}$ & 0.5 & 0.53 & 0.91 & 1.46 & 2.48 & 3.15 & 3.16 & 2.7 & 3.28 & 5.21 & 8.1 & 14.49 \\
\hline Gambling income $\left(\times 10^{9} \text { US } \$\right)^{\mathrm{a}}$ & 0.218 & 0.23 & 0.44 & 0.87 & 1.77 & 2.09 & 2.16 & 1.63 & 1.99 & 3.58 & 5.36 & 10.2 \\
\hline World emergy/US $\$\left(\times 10^{12} \mathrm{sej} / \text { US\$ }\right)^{\mathrm{b}}$ & 2.2 & 2.22 & 2 & 2 & 1.98 & 1.98 & 1.98 & 1.98 & 1.66 & 1.66 & 1.66 & 1.13 \\
\hline $\begin{array}{l}\text { Macao's emergy/US\$ } \\
\quad\left(\times 10^{12} \mathrm{sej} / \mathrm{US} \$\right)^{\mathrm{c}}\end{array}$ & 8.76 & 8.66 & 6.64 & 5.78 & 4.36 & 3.13 & 2.66 & 3.06 & 3.03 & 2.78 & 2.38 & 1.82 \\
\hline Emergy used $\left(\times 10^{20} \mathrm{sej}\right)^{\mathrm{c}}$ & 100.45 & 118.5 & 154.73 & 188.73 & 247.02 & 217.31 & 196.54 & 186.82 & 187.6 & 219.73 & 245.21 & 349.00 \\
\hline Service imports $\left(\times 10^{20} \text { sej }\right)^{\mathrm{c}}$ & 2.61 & 3.28 & 4.05 & 5.6 & 8.93 & 10 & 12.45 & 14.34 & 13.25 & 17.4 & 23.77 & 99.33 \\
\hline Imported emergy $\left(\times 10^{20} \mathrm{sej}\right)^{\mathrm{c}}$ & 92.98 & 111.04 & 149.07 & 184.88 & 243.15 & 213.44 & 192.65 & 182.94 & 183.72 & 215.86 & 241.34 & 345.03 \\
\hline Exported emergy $\left(\times 10^{20} \mathrm{sej}\right)^{\mathrm{c}}$ & 61.84 & 92.06 & 118.29 & 133.07 & 132.94 & 120 & 106.09 & 111.08 & 131.25 & 147.34 & 178.03 & 256.99 \\
\hline$T_{\mathrm{m}}\left(\times 10^{20} \mathrm{sej}\right)^{\mathrm{c}}$ & 11.05 & 11.77 & 18.24 & 29.21 & 49.09 & 62.43 & 62.63 & 53.43 & 54.49 & 86.5 & 134.56 & 163.47 \\
\hline Gambling income $\left(\times 10^{20} \mathrm{sej}\right)^{\mathrm{c}}$ & 4.61 & 5.11 & 8.87 & 17.4 & 35 & 41.4 & 42.7 & 32.4 & 33.1 & 59.4 & 89.03 & 115.03 \\
\hline $\begin{array}{l}\text { Tourist consumption } \\
\quad \text { ratio }\left(R_{\mathrm{t}}\right)^{\mathrm{C}}\end{array}$ & 0.096 & 0.095 & 0.113 & 0.114 & 0.102 & 0.096 & 0.108 & 0.112 & 0.124 & 0.148 & 0.174 & 0.267 \\
\hline$M_{\mathrm{t}}\left(\times 10^{20} \mathrm{sej}\right)^{\mathrm{c}}$ & 9.56 & 11.28 & 17.54 & 21.61 & 25.24 & 20.94 & 21.2 & 20.95 & 23.29 & 32.54 & 42.60 & 93.03 \\
\hline$T_{\mathrm{m}} / \mathrm{GDP}\left(\%\right.$, US\$ basis) ${ }^{\mathrm{c}}$ & 44 & 38.7 & 39.1 & 44.8 & 43.7 & 45.4 & 45.1 & 44.2 & 53 & 65.9 & 78.6 & 75.7 \\
\hline$T_{\mathrm{m}} / U(\%, \text { sej basis })^{\mathrm{c}}$ & 11.1 & 10 & 11.7 & 13.8 & 18.7 & 26.6 & 33.5 & 28.6 & 29 & 39.3 & 54.9 & 46.8 \\
\hline Gambling/GDP (\%, US\$ basis) ${ }^{\mathrm{c}}$ & 18.3 & 16.8 & 19.0 & 26.6 & 31.1 & 30.1 & 30.8 & 26.8 & 32.1 & 45.3 & 52.0 & 53.3 \\
\hline Gambling/U (\%, sej basis $)^{\mathrm{c}}$ & 4.6 & 4.3 & 5.7 & 8.2 & 13.3 & 17.6 & 22.8 & 17.3 & 17.6 & 27 & 36.3 & 33.0 \\
\hline
\end{tabular}

a Data obtained from Statistics and Census Service (2008).

b Data from Zhang et al. (2008).

c Data source: Indicators before 2003 are from Lei and Wang (2008), indicators from 2004 are from Lei et al. (2008), and indicators from 2007 were calculated using the data from the present study. 


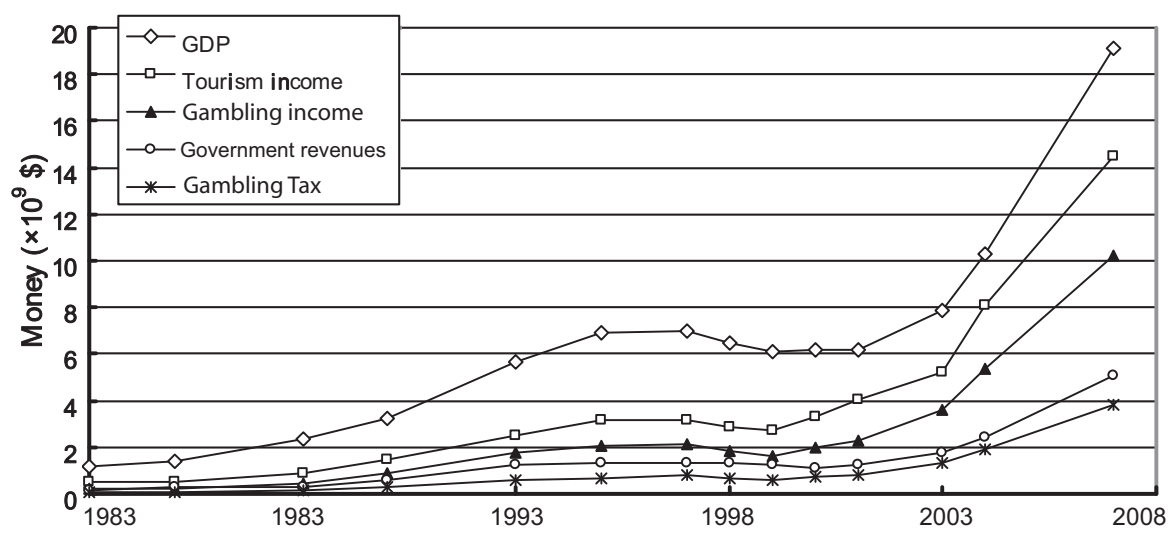

Fig. 4. Monetary flows for Macao from 1983 to 2007.

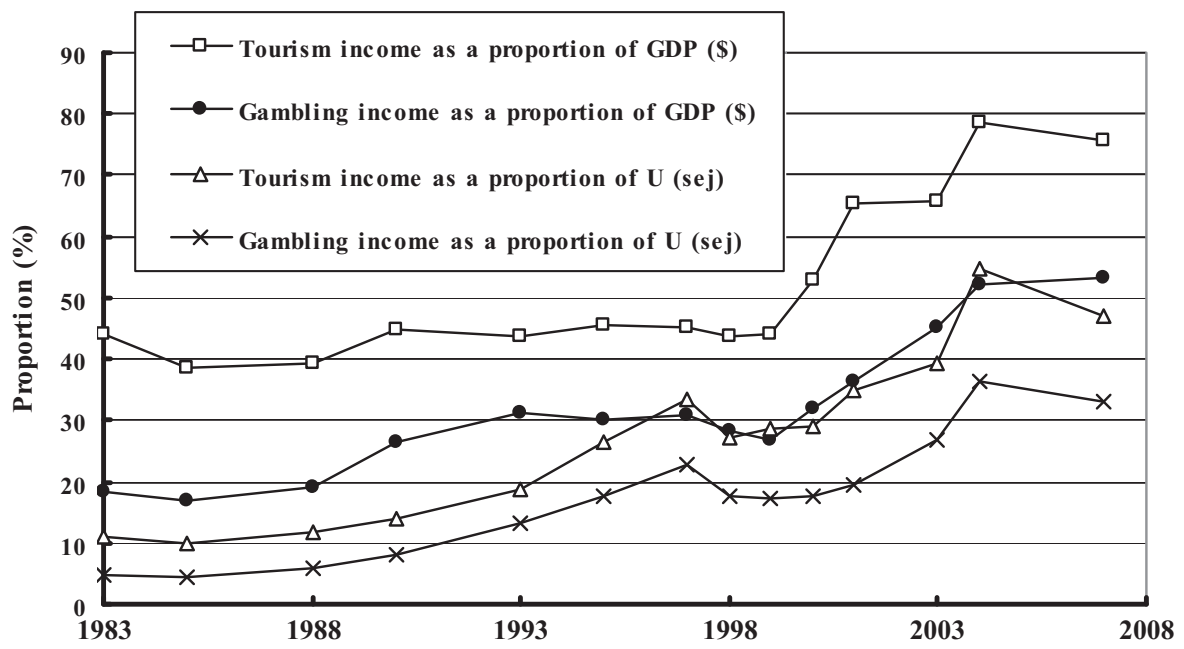

Fig. 5. The proportions of GDP accounted for by the tourism and gambling industries, and the corresponding proportions of total emergy use ( $U$ ) from 1983 to 2007.

These results can be explained by changes in the components of different industries and their development during this period. Tourism, manufacturing, finance and insurance, and construction and real estate had been thought of as the four pillars of Macao's economy in the 1980s (Miao et al., 1988). However, Macao has become a consumer society since 1990 , following the abandonment of agriculture and the decline of the local fishing industry. Moreover, the manufacturing sector migrated to southern China around this time. From 1997 to 2000, the GDP decreased in response to a decrease in gambling income and tourism as a result of increased criminal activity and a corresponding decrease in tourist interest in visiting the city (Lei and Wang, 2008). Since 2000, Macao's economy has experienced robust growth as a result of a more holistic view that has emphasized other aspects of the economy (e.g., the city's cultural and natural heritage), combined with more effective public security and the sustained prosperity of China, leading to increases in tourist visits from China.

Fig. 6 shows the changes in $T_{\mathrm{m}}, M_{\mathrm{t}}$, and gambling income from 1983 to 2007. Both $T_{\mathrm{m}}$ and $M_{\mathrm{t}}$ peaked between 1995 and 1997 , decreased briefly, then increased once more. The emergy received from Macao's tourism industry represents the emergy converted from the monetary income provided by tourism $\left(T_{\mathrm{m}}\right)$, and the

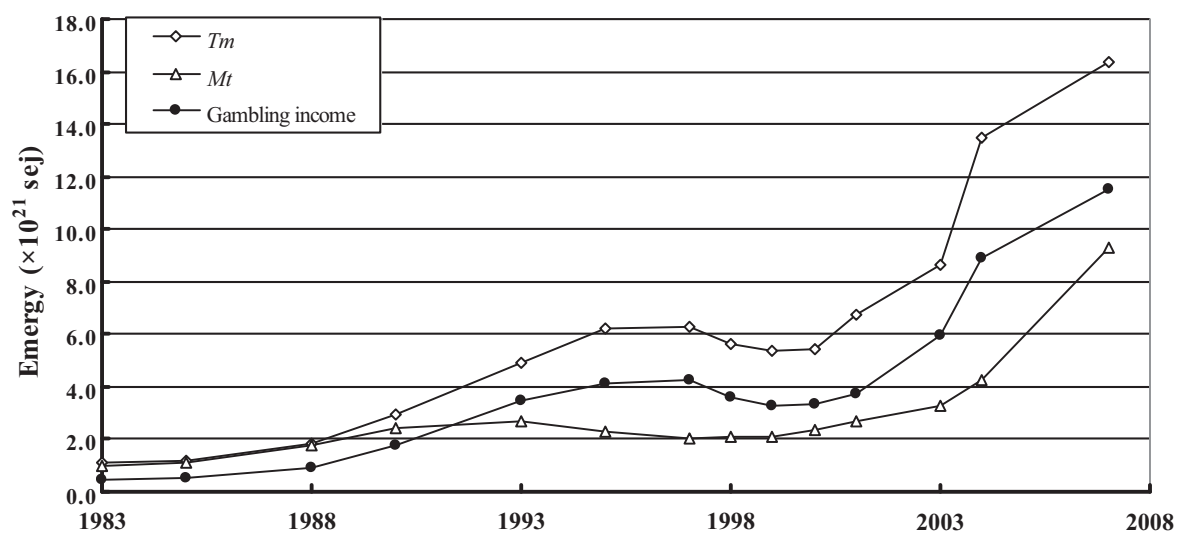

Fig. 6. Emergy trends for $T_{\mathrm{m}}, M_{\mathrm{t}}$, and gambling income from 1983 to 2007. 
emergy of tourist consumption is the emergy provided to the tourists $\left(M_{\mathrm{t}}\right)$. The emergy of tourism $\left(T_{\mathrm{m}}\right)$ increased from $11.1 \times 10^{20}$ sej in 1983 to $163.5 \times 10^{20}$ sej in 2007. During the same period, $M_{\mathrm{t}}$ increased from $9.56 \times 10^{20} \mathrm{sej}$ to $93.0 \times 10^{20} \mathrm{sej}$. Gambling income peaked between 1995 and 1997, decreased briefly, and then began to increase again. The proportion of total emergy use $(U)$ that was consumed by tourists $\left(R_{\mathrm{t}}\right)$ increased steadily, from 0.096 in 1983 to 0.267 in 2007 (Table 5).

This analysis has shown that more emergy wealth is imported than exported in Macao's tourism industry. The tourism-related emergy flows, storage, and indices all changed to follow the rapid changes in Macao's socioeconomic system. Accompanying the sustained growth of tourism from mainland China and the construction of new casinos, the expenditures of non-gambling tourism was increased (Fig. 4), mainly as a result of two factors: (1) Macao is a port where people, cargo, and capital are generally allowed to flow freely. The lower tax rates and prices for gold, jewellery, and cosmetics compared with Mainland China attracts many Chinese visitors, who spend large amounts of money on these and other goods. (2) Chinese visitors also spend large amounts of money consuming the services provided by Macao (Statistics and Census Service, 2008).

\section{Conclusions}

Ecological tourism appeals to ecologically and socially conscious individuals. It typically involves travel to destinations where the flora, fauna, and cultural heritage are the primary attractions, although visitors motivated by the latter attraction are often referred to as "cultural heritage tourists" rather than ecotourists. Cultural attractions are an important part of tourism at levels ranging from global highlights to the lesser attractions that underpin a local culture's identity (Richards, 2001). However, culture has increasingly been rediscovered as an important marketing tool to attract travelers who are interested in a region's heritage. Responsible ecotourism includes programs that minimize the negative aspects of conventional tourism on the environment and enhance the cultural integrity of local peoples. This would have the additional beneficial effect of diversifying Macao's tourism economy, making it more resistant to recessions or changes in tourist preferences.

In Macao, our data show that visitors were strongly attracted by gambling activities, and spent a large proportion of their money on gambling and related activities. Gambling has been legal in Macao since the 1850s, when the Portuguese government legalized the activity in their colony. However, the gambling industry has also been a source of instability in Macao's economy, as the nature of gambling business does not appear to be susceptible to technological advancement or productivity growth. The gambling business also depends strongly on the prosperity of other Asian economies, especially those of China and Hong Kong.

Sustainable tourism development depends on the wise use of resources and an understanding of the flows of energy embodied in these resources (i.e., the emergy flows). Due to a lack of data on services and imports from other regions, we used the world $\mathrm{Em} / \$$ ratio for all imported services. This approach undervalues the labor and service imports, since (for example) China's $\mathrm{Em} / \$$ value is higher than the global average (Lei and Wang, 2008), and using this higher value in our accounting would decrease the net emergy for Macao. Adopting the real $\mathrm{Em} / \$$ value for Macao and the regions that exchange emergy with the city would therefore increase the net emergy of Macao's system.

\section{Acknowledgments}

This research was supported by the National Natural Science Foundation of China (grants 70873121 and 70573106), the Key
Supporting Project of the Ministry of Science and Technology of China (grant 2007BAC28B04), the State Key Laboratory of Subtropical Building Sciences, South China University of Technology (grant 2008ZA09), and the Science and Technology Development Fund of Macao (grant 022/2007/A2), Macao Special Administrative Region, China. This work was also supported by the State Key Laboratory of Urban \& Regional Ecology (SKLURE2008-1-01).

\section{Appendix A. Supplementary data}

Supplementary data associated with this article can be found, in the online version, at doi:10.1016/j.ecocom.2011.02.002.

\section{References}

Abel, T., 2000. Ecosystems, sociocultural systems, and ecological-economics for understanding development: the case of tourism on the Bonaire, N.A. PhD Dissertation, University of Florida, Gainesville, Florida.

Abel, T., 2003. Understanding complex human ecosystems: the case of ecotourism on Bonaire. Conserv. Ecol. 7 (3), 7-10.

Baumgärtner, S., Quaas, M., 2010. Sustainability economics-General versus specific, and conceptual versus practical. Ecol. Econ. 69, 2056-2059.

Brandt-Williams, S., 2001. Handbook of Emergy Evaluation: Folio \#4, Emergy of Florida Agriculture. Center for Environmental Policy, University of Florida, Gainesville, Florida.

Brown, M.T., Bardi, E., 2001. Handbook of Emergy Evaluation: Folio \#3, A Compendium of Data for Emergy Computation Issued in a Series of Folios. Center for Environmental Policy, University of Florida, Gainesville, Florida.

Brown, M.T., Buranakarn, V., 2003. Emergy indices and ratios for sustainable material cycles and recycle options. Resour. Conserv. Recyc. 38, 1-22.

Brown, M.T., Ulgiati, S., 2001a. Emergy measures of carrying capacity to evaluate economic investments. Popul. Environ. 22, 471-501.

Brown, M.T., Ulgiati, S., 2001b. The role of environmental services in electricity production processes. J. Clean Prod. 10, 321-334.

Brown, M.T., Ulgiati, S., 2010. Updated evaluation of exergy and emergy driving the geobiosphere: a review and refinement of the emergy baseline. Ecol. Model. 221, 2501-2508.

Campbell, D.E., 2004. Evaluation and emergy analysis of the Cobscook Bay Ecosystem. Northeastern Nat. 11 (Special Issue 2), 355-424.

Campbell, D.E., Brandt-Williams, S.L., Meisch, M.E.A., 2005. Environmental Accounting Using Emergy: Evaluation of the State of West Virginia. U.S. Environmental Protection Agency, National Health and Environmental Effects Research Laboratory, Atlantic Ecology Division, Narragansett, RI, p. E-2.

Cuadra, M., Rydberg, T., 2006. Emergy evaluation on the production, processing end export of coffee in Nicaragua. Ecol. Model. 196, 421-433.

Franklin, A., 2003. Tourism: An Introduction. Sage Publications Ltd., London.

Gössling, S., Peeters, P., Ceron, J., Dubois, G., Patterson, T.M., Richardson, R., 2005. The eco-efficiency of tourism. Ecol. Econ. 54 (4), 417-434.

Huang, S.L., Odum, H.T., 1991. Ecology and economy: emergy synthesis and public policy in Taiwan. J. Environ. Manage. 32, 313-333.

Huang, S.L., Odum, H.T., 1996. Ecological Energy Evaluation of Urban System. James Publishing House, Taiwan (in Chinese).

Huang, S.L., 1998. Urban ecosystems, energetic hierarchies, and ecological economics of Taipei metropolis. J. Environ. Manage. 52, 39-51.

Hunter, C., Green, H., 1995. Tourism and the Environment. A Sustainable Relationship. Routledge, London.

Jiang, M.M., Zhou, J.B., Chen, B., Chen, G.Q., 2008. Emergy-based ecological account for the Chinese economy in 2004. Commun. Nonlinear Sci. Numer. Simulat. 13, 2337-2356.

Johansson, S., Doherty, S.J., Rydberg, T., 2000. Sweden food system analysis. In: Brown, M.T., Brandt-Williams, S., Tilley, D., Ulgiati, S. (Eds.), Emergy Synthesis: Theory and Applications of the Emergy Methodology. The Centre for Environmental Policy, University of Florida, Gainesville, pp. 211-222.

Lan, S.F., Qing, P., Lu, H.F., 2002. The Emergy Analysis of Ecological Economy System. Chemical Industry Publishers, Beijing (in Chinese).

Lei, K.P., Chen, F.P., Wang, Z.S., 2006. The energy synthesis and sustainability analysis of city's environment and economy. Acta Ecol. Sin. 26, 439-448 (in Chinese).

Lei, K.P., Wang, Z.S., 2008. Emergy synthesis of a tourism-based urban ecosystem. J. Environ. Manage. 88, 831-844.

Lei, K.P., Wang, Z.S., Tong, S.S., 2008. Holistic emergy analysis of Macao. Ecol. Eng. $32,30-43$.

Lei, K.P., Zhou, S.Q., Hu, D., Yu, Y.Y., 2010. Ecological energy accounting for the gambling sector: a case study in Macao. Ecol. Complex. 7, 149-155.

Li, D., Wang, R., 2009. Hybrid emergy-LCA (HEML) based metabolic evaluation of urban residential areas: the case of Beijing, China. Ecol. Complex. 6, 482-491.

Miao, H.K., Ho, D.Ch., Lei, Q., Zheng, T.X., Wong, Ch.S., 1988. Macao. Sun Yatsen University Press, Guangzhou (in Chinese).

Odum, H.T., 1996. Environmental Accounting: Emergy and Decision Making. Wiley, New York. 
Odum, H.T., Odum, E.C., 1980. Energy Basis for Man and Nature. McGraw-Hill, New York.

Ren, J.M., Zhang, L., Wang, R., 2010. Measuring the sustainability of policy scenarios: emergy-based strategic environmental assessment of the Chinese paper industry. Ecol. Complex. 7, 156-161.

Richards, G., 2001. Cultural Attractions and Europe Tourism. CABI Publishing, New York.

Statistics and Census Service, 2008. Yearbook of Statistics, 2007. Government Printing Bureau, Macao http://www.dsec.gov.mo/default.aspx?lang=en-US.

Ulgiati, S., Brown, M.T., 2009. Emergy and ecosystem complexity. Commun. Nonlinear Sci. Numer. Simulat. 14, 310-321.
Ulgiati, S., Odum, H.T., Bastianoni, S., 1994. Emergy use, environmental loading and sustainability, an emergy analysis of Italy. Ecol. Model. 73, 215-268.

Vassallo, P., Paoli, C., Tilley, D.R., Fabiano, M., 2009. Energy and resource basis of an Italian coastal resort region integrated using emergy synthesis. J. Environ. Manage. 91, 277-289.

Zhang, L.X., Chen, B., Yang, Z.F., Chen, G.Q., Jiang, M.M., Liu, G.Y., 2009. Comparison of typical mega cities in China using emergy synthesis. Commun. Nonlinear Sci. Numer. Simulat. 14, 2827-2836.

Zhang, Y., Zhao, Y.W., Yang, Z.F., Chen, B., Chen, G.Q., 2008. Measurement and evaluation of the metabolic capacity of an urban ecosystem. Commun. Nonlinear Sci. Numer. Simulat. 14, 1758-1765. 